\title{
Store-Related Factors Contributing to Offline Private Label Brands Purchase Intention among Gen Y Customers
}

\author{
Sawanah Binti Mumin \\ Faculty of Business, Economics and Accountancy, Universiti Malaysia Sabah, Kota \\ Kinabalu, Malaysia \\ Phang Ing @ Grace \\ Faculty of Business, Economics and Accountancy, Universiti Malaysia Sabah, Kota \\ Kinabalu, Malaysia
}

\begin{abstract}
The purpose of this study is to examine store-related factors contributing to the purchase intention towards private label brands (PLBs) among Gen Y customers in Kota Kinabalu, Sabah. Representing one of the biggest market segments in Malaysia, Gen $\mathrm{Y}$ is considered more open-minded to try new products than Baby Boomers. However, retail research focusing on Gen Y, particularly their buying intention of PLBs product, is scarce. A purposive sampling technique was utilised and a total of 300 questionnaires were distributed among Gen Y shoppers aged 23-39, who frequented supermarkets and drugstores. This study generated 240 usable responses ( $80 \%$ response rate). All the store-related variables were found to have significant relationships with attitude towards purchasing PLBs product, which in turn, affected purchase intention. Attitude mediated the relationships between all the store-related variables and purchase intention. Product category and retail format significantly moderated the relationship between attitude and purchase intention. This study benefits academic and marketing practitioners by expanding on previous literature towards customer behaviour, which the marketing practitioners could benefit from the private label initiative as well as have a better understanding of their target customers to further enhance the sales among the Gen Y customers.
\end{abstract}

Keywords: Store-Related Factors, Private Label Brands (PLBs), Gen Y, Purchase Intention, Attitude. 


\section{Introduction}

Private label brands (PLBs) are brands manufactured by particular manufacturers and sold under other business names (Valaskova, Kliestikova \& Krizanova, 2018). PLBs are also known as store brands, retailer brands, or in-house brands where the brands are owned by distributors and sold in exclusive stores (Kotler \& Armstrong, 2016). In this regard, PLBs products are considered as home brands or own-brand products sold under a retail store's name or under a brand name created specifically by a retailer for that store (Lin, Gao \& Safar, 2018).

Scholars have argued that PLBs was introduced as an economy product to serve the budget segment by offering customers lower quality and price compared to more established national brands (Boyle \& Lathrop, 2013). Moreover, in order to compete more effectively, PLBs are found to improve their quality by distinguishing themselves through packaging which is more attractive, good quality, and affordable price (Fong, Kian, Fern \& Vincent, 2015).

The development of PLBs is not similar across different regions. Customers in more developed markets (such as the United States) often regard the PLBs as good as a national brand while customers in the Asia Pacific, Middle East, and Africa perceive PLBs rather negatively (Euromonitor, 2013). The market share of the PLBs has remained steady around $10-15 \%$ in most of the countries in the world (McCaskill, 2014). PLBs development in Malaysia is low as 2\% (The Nielsen Company, 2014). To understand the underneath reasons for the different acceptance levels of PLBs, the market responses require closer examination, particularly in Asia Pacific markets where the demand is generally discouraging.

Thus, it is critical to examine what are the factors driving customers' intention to buy PLBs. Therefore, this study attempts to extend and fill the gap of the previous studies by examining the factors contributing to the purchase intention, particularly among Gen Y customers or 'echo boomers' or the 'millennium generation'. It is important to note that Gen Y comprises of those born between 1980 and 1996 (Schiffman \& Wisenblit, 2015), the largest population segment in Malaysia (DOSM, 2019). Gen Y customers are found to be more open-minded in trying new products (including PLBs) compared to Baby Boomers (The Nielsen Company, 2018).

As there are still limited studies on PLBs, particularly in Malaysia, this study's findings will provide valuable insights to practitioners to create a better understanding of their target customers to provide better services to their customers. This study examined the impacts of store-related factors on attitudes toward purchasing PLB and later on, the purchase intention. In addition, retail format and product category served as moderating factors in the relationship between attitude and purchase intention.

\section{Literature Review}

\section{Perceived Quality and Attitude}

Customers nowadays enjoy more choices to buy, especially in purchasing products with similar quality at a cheaper price (Vo \& Nguyen, 2015). Perception of quality normally 
depends on customers' preferences or interests, and this influences their attitude towards products or services that contribute to higher value perception (Tomasevic, Novakovic, Solowiej, Zdolec, Skunca, Krocko, Nedomova, Kolaj, Aleksiev \& Djekic, 2018). In regard to fast-moving consumer goods, perceived quality attracts the customer in terms of services provided (Al-Debei, Akroush \& Ashouri, 2015). In this study, customers are expected to have more positive attitudes toward PLBs when they perceive the PLBs are good quality. Therefore, the first hypothesis is as follows:

H1 Perceived quality has a positive relationship with attitude towards using PLBs.

\section{Perceived Product Similarity and Attitude}

Perceived product similarity happens when people see the product within the same category have high similarity (Kuswoyo, Suliyanto \& Setyanto, 2019). The products that have almost the same attributes could be perceived as substitutes by customers (Wang, Jin \& Yang, 2020). Variations in individual factors (motives, buying experience and etc.) could lead to different perceptions of the same stimuli by different customers. Nevertheless, it is generally agreed that the more similar a PLB to a well-known national brand, it will be perceived to be a substitute and hence enjoy more positive attitudes. Hence, the second hypothesis formulated is as follow:

H2 Perceived product similarity has a positive relationship with attitude towards using PLBs.

\section{Perceived Risk and Attitude}

Perceived risk differs across different product categories as well as buying situations (Manikandan, 2020). The advancement of today's technology allows customers to easily search for product-related information prior to making purchase decisions to minimize their risks (Manikandan, 2020). In other words, the higher the perceived risk, the less favourable a buying option to be. Due to their higher perceived risks and the nature of people to avoid risks in their decision-making process, customers could have form negative attitudes toward PLBs. Thus, the third hypothesis formulated is as follows:

H3 Perceived risk has a negative relationship with attitude towards using PLBs.

\section{Store Loyalty and Attitude}

Store loyalty is the frequency of store visits (Seenivasan, Sudhir \& Talukdar, 2016). PLBs contribute to store loyalty in a way that these brands are only exclusively available at specific retailers (Gangwani, Mathur \& Shahab, 2020). This is different from national brands which are sold in competing retailers or any other retail stores. Hence, introducing PLBs is a good strategy to build store loyalty and an effective marketing tool to attract store traffic as well as create a point of differentiation (Beneke \& Zimmerman, 2014). Customers who are loyal to a particular product and brand will find it difficult to change or switch to another product or brand and will be less likely to seek substitution. This is consistent in the case of a store whereby the spill-over effect of the store loyalty to PLBs could happen. Hence, the following hypothesis is formulated: 
H4 Store loyalty has a positive relationship with attitude towards using PLBs.

\section{Store Image and Attitude}

Image act as a function of salient attributes of a particular store that are evaluated and weighed against each other (Demirgüneş, 2014). Previous studies by Norfarah, Koo, and Siti-Nabiha (2018) found that positive store image leads to positive attitudes and later, higher purchase intention. This further leads to the spill-over effect on PLBs. In other words, a positive store image would lead to a more positive attitude towards using the PLBs. The fifth hypothesis is as followed:

H5 Store image has a positive relationship with attitude towards using PLBs.

\section{Attitude towards using PLBs and Purchase Intention}

Attitude is formed when people learn to behave consistently, either favourable or unfavourable, towards a given object (Schiffman \& Wisenblit, 2015), meanwhile purchase intention can be defined as a tendency to purchase a specific brand in the future and normally related to behaviour, perception, and attitude (Mirabi, Akbariyeh \& Tahmasebifard, 2015). It is stipulated that customer attitude tends to change over time (Schiffman \& Wisenblit, 2015) and the most important element in predicting customers' choice of products and services (Zhang \& Kim, 2013).

The predictive power of attitude on purchase intention has been well established and confirmed in studies across various fields and product categories. For instance, in Hwang, Chung \& Sanders (2016)'s study on PLBs, the attitude was found to be the most important contributing factor to purchase intention. Similar findings were found in Gómez-Suárez, Paiva \& Schnettler (2016)'s study. Consistently, this study predicts that a more favourable attitude will lead to higher buying intention of PLBs. The following hypothesis is formed:

H6 Attitude towards using PLBs has a positive relationship on the purchase intention.

\section{The Mediation Effect of Attitude}

Attitudes shape a customer's intention in a distinct way (Lin, Gao \& Safar, 2018). Souki, Antonialli, Barbosa, and Oliveira (2019) proved the mediation role of attitude in the relationship between perceived quality and purchase intention. However, Wang, Tao \& Chu's (2020) study posit a significant direct relationship between these two variables. In this study, it is assumed that customers will only form higher intention to buy PLBs when they hold favourable attitudes towards them based on the perceived product quality.

Customers in European countries, for instance, are found to higher intention to purchase PLBs as they do not perceive much difference in terms of quality and durability dimensions compared to their American counterparts. Moreover, Wang, Jin \& Yang (2020) predicts a greater consumption of similar products and attitude towards these similar products could lead to higher purchase intention. Based on these studies, it is posited that attitude plays a mediating role between perceived product similarity and 
purchase intention.

Manikandan (2020) stated that perceived risk significantly influences attitude towards PLBs. Meanwhile, in Aldousari, Yasmin, Ab Yajid \& Ahmed's (2017) study, perceived risk has a significant direct relationship with purchase intention. The mediating role of attitude between perceived risk and purchase intention is hence assumed.

Gázquez-Abad, Martínez-López, Mondéjar-Jiménez and Esteban-Millat (2015) found that attitude towards store brands has a direct effect on store loyalty in the Spanish market, while Mathur and Gangwani (2016) found that loyalty has a positive relationship with purchase intention. Therefore, attitude is posited to play a mediating role between store loyalty and purchase intention.

The findings presented in Norfarah et al. (2018) posited that the more customers think about a store's image, they will form a more positive evaluation towards the PLBs. Erdil (2015) also stated that store image directly affects purchase intention of PLBs product. Based on these previous studies, this study assumes that attitude plays a mediating role in the relationship between store image and purchase intention. Thus, the following hypotheses were developed:

H7a Attitude towards using PLBs mediates the relationship between perceived quality and purchase intention.

H7b Attitude towards using PLBs mediates the relationship between perceived product similarity and purchase intention.

H7c Attitude towards using PLBs mediates the relationship between perceived risk and purchase intention.

H7d Attitude towards using PLBs mediates the relationship between store loyalty and purchase intention.

H7e Attitude towards using PLBs mediates the relationship between store image and purchase intention.

\section{Product category and retail format act as moderators}

Customers have a less favorable attitude towards PLBs in non-food product categories because they perceive that the quality differences between PLBs and manufacturer brands are higher than it really is (The Nielsen Company, 2014). This can be explained by the fact that in regard to determining food quality, customers are able to taste the product and thus better assess the quality of PLBs compared to the quality of manufacturer brands. On the other hand, as the quality of non-food products is harder to assess, customers often associate the brand name with quality. Differences in attitude towards PLBs in different product categories are confirmed in Komissarova, Mayorova, Nikishin, Rozhnova and Mayorova (2017) study.

Several studies have examined customer shopping behaviour across different retail formats (Ing, Ivan \& Osman, 2019). Retail format choices differ across customer attributes such as gender (Johansson \& Kask, 2017) and buying motives. Different retail 
markets target different customer groups with different buying motives and behaviours and adhere to their retail strategies accordingly. Supermarket for instance would focus more on grocery merchandise, while drugstores would focus more on health and beauty care products. Based on these arguments, this study posits that product category and retail format moderate the relationship between attitude towards using PLBs and purchase intention. The following hypotheses are developed:

H8a Product category moderates the relationship between attitude towards using PLBs and purchase intention.

H8b Retail format moderates the relationship between attitude towards using PLBs and purchase intention.

Figure 1: Research Framework

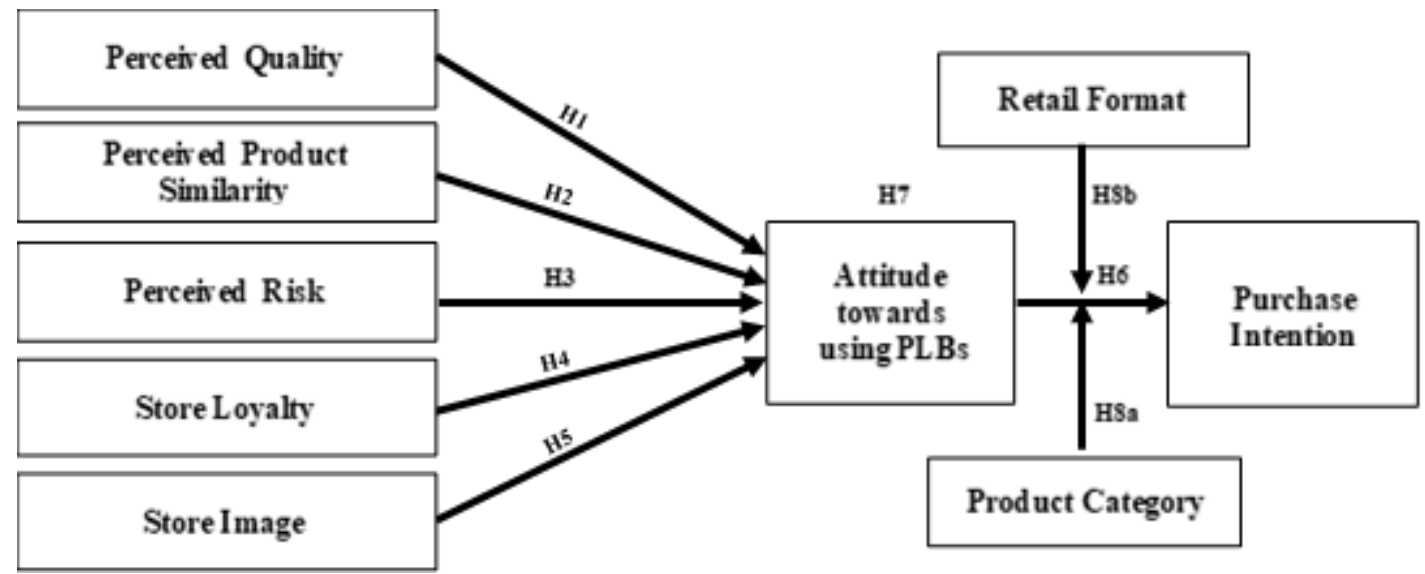

Source: Thanasuta, K., (2015), "Thai consumers' purchase decisions and private label brands", International Journal of Emerging Markets, vol. 10, no. 1, pp. 102-121.

\section{Methodology}

This study examined five store-related variables, namely perceived quality, perceived product similarity, perceived risk, store loyalty, and store image on their relationships with attitudes towards using PLBs. Attitude also acts as a mediator in the relationships between the store-related variables and purchase intention, while product category and retail format served as moderators.

As the population size is undetermined, a non-probability purposive sampling technique was adopted. A self-administered questionnaire was used. The questionnaire was available in bilingual to suit the multi-ethnicity and multilingual Malaysian society. The translation procedure followed Douglas and Craig (2007)'s collaborative and iterative approach. The use of parallel or double translation has been advocated as a preferred method (Van de Vijver \& Hambleton, 1996). Cognitive interviews were also conducted with 10 independent respondents prior to the main test.

Prior to data collection at selected supermarkets and drugstores, two screening questions were asked to ensure the suitability of the respondents. First, the respondents must age between 23-39 years old; and second, they must have heard of or used PLBs 
product before. Only respondents who fulfilled both criteria were allowed to take part in the survey. The selected age group comprised of Gen Y customers who represent the largest segment in Malaysia and Sabah (DOSM, 2019).

The sample size is an important element in any study or investigation in order to draw a conclusion about the population from the sample. $G^{*}$ Power analysis with the effect size of 0.15 (Cohen, 1988) was run to determine the minimum required sample size and the test generated a minimum number of 184 responses. A total number of 240 valid responses were collected for the main study out of 300 questionnaires distributed (response rate of 80 percent). The figure exceeded the minimum requirements of 184 and is considered appropriate and acceptable for analysis.

The questionnaire items were adopted and adapted from literature with modifications to suit the study. All of the items used a 5-point Likert scale, 1=strongly disagree, $5=$ strongly agree. Perceived quality was adopted from Mostafa and Elseidi (2018). Perceived product similarity was adopted from Kuswoyo, Suliyanto and Setyanto (2019). Perceived risk was adopted from Aldousari et al. (2017). Store loyalty was adopted from Coelho do Vale, Matos and Caiado (2016) and store image adopted from Diallo, Burt and Leigh (2015). Attitude towards using PLBs was adopted from Cheah, Phau and Liang (2015) and purchase intention was adopted from Diallo and Siqueira (2017). The data was analysed using Statistical Package for the Social Sciences version 26 (SPSS) and Partial Least Square Equation Modeling (PLS-SEM) via Smart PLS version 3.0 path modelling pathway.

\section{Results}

\section{Respondents' Profile}

Table 1 shows the profile of the respondents. The majority of the respondents are female $(67.1 \%)$ with the minimum qualifications of a bachelor's degree $(27.5 \%)$. The majority of them work in the private sector $(47.1 \%)$ with a monthly income ranging from RM 1,001- RM 4,000 (68.3\%). Most are married (49.6\%) and have 5-6 family members $(32.5 \%)$. The samples were recruited in supermarkets and drugstores, focused on grocery and non-grocery products.

\section{Common Method Bias}

Common method bias is caused by the variance in the responses due to the adopted measurements rather than the respondents (Brannick, Chan, Conway, Lance \& Spector, 2010). As this study employed a cross-sectional survey, common method bias may be a concern in affecting study results. Harman's Single factor test was carried out and the extracted sum of squared loading for the first variable is $20.50 \%$. This is lower than the cut-off point of 50\% suggested by Podsakoff, MacKenzie, Lee and Podsakoff (2003). Therefore, the data do not suffer from common method variance. 
Table 1: Profile of Respondents

\begin{tabular}{|c|c|c|c|}
\hline Demographic Variables & Categories & Frequency & Percent \\
\hline \multirow{2}{*}{ Gender } & Male & 79 & 32.9 \\
\hline & Female & 161 & 67.1 \\
\hline \multirow{2}{*}{ Age } & $21-30$ & 103 & 42.9 \\
\hline & $31-40$ & 137 & 57.1 \\
\hline \multirow{7}{*}{ Level of Education } & SPM & 37 & 15.4 \\
\hline & STPM & 24 & 10.0 \\
\hline & Diploma & 48 & 20.0 \\
\hline & Bachelor & 66 & 27.5 \\
\hline & Master & 45 & 18.8 \\
\hline & $\mathrm{PhD}$ & 6 & 2.5 \\
\hline & Others & 14 & 5.8 \\
\hline \multirow{4}{*}{ Occupations } & Government & 59 & 24.6 \\
\hline & Private Sector & 113 & 47.1 \\
\hline & Self-employed & 24 & 10.0 \\
\hline & Others & 44 & 18.3 \\
\hline \multirow{4}{*}{ Monthly Income } & Less than RM1,000 & 38 & 15.8 \\
\hline & RM1,001 - RM4,000 & 164 & 68.3 \\
\hline & RM4,001 - RM9,000 & 32 & 13.3 \\
\hline & More than RM9,000 & 6 & 2.5 \\
\hline \multirow{4}{*}{ Marital Status } & Single & 104 & 43.3 \\
\hline & Married & 119 & 49.6 \\
\hline & Divorced & 11 & 4.6 \\
\hline & Widow & 6 & 2.5 \\
\hline \multirow{4}{*}{ Members in Family } & 1-2 members & 35 & 14.6 \\
\hline & 3-4 members & 73 & 30.4 \\
\hline & 5-6 members & 78 & 32.5 \\
\hline & More than 7 & 54 & 22.5 \\
\hline
\end{tabular}

\section{Analysis of Measurement Model}

This study used the PLS approach to analyse the measurement and structural models. The measurement model was first examined to measure reliability, convergent validity, and discriminant validity. A structural model was then formed to test the hypotheses.

Table 2 shows the consistency, reliability and convergent validity of the measurement model. According to Hair, Black, Babin and Anderson (2010), all the factor loadings must exceed the recommended threshold value of 0.5 . The loadings generated from the data range from 0.711 to 0.903 which are above the threshold of 0.50 . The average variance extracted (AVE) of the constructs range from 0.574 to 0.734 that which exceed the recommended threshold value of 0.5 (Hair, Hult, Ringle \& Sarstedt, 2016). The composite reliability (CR) values range from 0.843 to 0.917 exceeding the recommended threshold value of 0.7 as mentioned in Hair et al. (2016). Similarly, all the Cronbach's Alpha coefficients range from 0.759 to 0.879 which exceeds the recommended value of 0.70 (Nunnally, 1978). Based on the result, we can conclude that there is adequate convergence validity of the constructed measurement model. 
Table 2: Internal Consistency Reliability and Convergent Validity

\begin{tabular}{|c|c|c|c|c|c|}
\hline Construct & Indicators & Loading & $\begin{array}{l}\text { Composite } \\
\text { reliability }\end{array}$ & $\begin{array}{c}\text { Cronbach's } \\
\text { Alpha }\end{array}$ & AVE \\
\hline \multirow{3}{*}{ Perceived quality } & PQ1 & 0.802 & 0.872 & 0.78 & 0.695 \\
\hline & PQ2 & 0.884 & & & \\
\hline & PQ3 & 0.812 & & & \\
\hline \multirow{4}{*}{$\begin{array}{l}\text { Perceived product } \\
\text { similarity }\end{array}$} & PPS2 & 0.788 & 0.843 & 0.759 & 0.574 \\
\hline & PPS3 & 0.711 & & & \\
\hline & PPS5 & 0.789 & & & \\
\hline & PPS6 & 0.74 & & & \\
\hline \multirow{5}{*}{ Perceived risk } & PR2 & 0.767 & 0.907 & 0.875 & 0.662 \\
\hline & PR3 & 0.785 & & & \\
\hline & PR4 & 0.845 & & & \\
\hline & PR5 & 0.859 & & & \\
\hline & PR6 & 0.809 & & & \\
\hline \multirow{3}{*}{ Store loyalty } & SL1 & 0.899 & 0.891 & 0.826 & 0.734 \\
\hline & SL2 & 0.903 & & & \\
\hline & SL3 & 0.759 & & & \\
\hline \multirow{5}{*}{ Store image } & SI4 & 0.705 & 0.891 & 0.848 & 0.622 \\
\hline & SI6 & 0.828 & & & \\
\hline & SI7 & 0.845 & & & \\
\hline & SI8 & 0.791 & & & \\
\hline & SI9 & 0.767 & & & \\
\hline \multirow{4}{*}{$\begin{array}{l}\text { Attitude toward } \\
\text { using PLBs }\end{array}$} & AT1 & 0.86 & 0.917 & 0.879 & 0.734 \\
\hline & AT2 & 0.881 & & & \\
\hline & AT3 & 0.852 & & & \\
\hline & AT4 & 0.833 & & & \\
\hline \multirow{4}{*}{ Purchase Intention } & PI1 & 0.765 & 0.892 & 0.839 & 0.675 \\
\hline & PI2 & 0.852 & & & \\
\hline & PI3 & 0.852 & & & \\
\hline & PI4 & 0.815 & & & \\
\hline
\end{tabular}

Note: AVE = average variance extracted, CR = composite reliability; PPS1, PPS4, PQ4, PR1, SI1, SI2, SI3, SI5 and SI10 with low loadings were subsequently dropped.

The next analysis is to determine the discriminant validity. The examination of the Fornell and Larcker's Criterion presented in Table 3 shows that the indicators load more strongly on their own constructs than other constructs in the model. Moreover, the average variance shared between each construct and its measures are greater than the variance shared between the constructs and other constructs (Fornell \& Larcker, 1981). The square root of the AVE at the diagonals was found to exceed the off diagonals element in the corresponding row and column. 
Table 3: Fornell and Larcker's Criterion Test

\begin{tabular}{cccccccc}
\hline & AT & PI & PPS & PR & PQ & SI & SL \\
\hline AT & $\mathbf{0 . 8 5 7}$ & & & & & & \\
PI & 0.623 & $\mathbf{0 . 8 2 2}$ & & & & & \\
PPS & 0.304 & 0.281 & $\mathbf{0 . 7 5 8}$ & & & & \\
PR & -0.187 & -0.143 & 0.098 & $\mathbf{0 . 8 1 4}$ & & & \\
PQ & 0.45 & 0.378 & 0.235 & -0.095 & $\mathbf{0 . 8 3 4}$ & & \\
SI & 0.33 & 0.208 & 0.173 & -0.165 & 0.204 & $\mathbf{0 . 7 8 9}$ & \\
SL & 0.3 & 0.302 & 0.133 & -0.08 & 0.116 & 0.349 & $\mathbf{0 . 8 5 7}$ \\
\hline
\end{tabular}

Note: Diagonals represent the square root of the AVE while the off diagonals represent the correlations. $\mathrm{AT}=$ Attitude towards using PLB, PI $=$ Purchase Intention, $\mathrm{PPS}=$ Perceived Product Similarity, $\mathrm{PQ}=$ Perceived Quality, SI= Store Image, $\mathrm{SL}=$ Store Loyalty.

Table 4 illustrates the assessment of discriminant validity using the HTMT technique, as proposed by Henseler, Ringle and Sarstedt (2014). As shown in Table 4, all the values fulfill the criterion of HTMT.90 (Gold, Malhotra \& Segars, 2001) and the HTMT.85 (Kline, 2015). In addition, the bootstrapping procedure with 5,000 samples is performed using the no sign changes option, BCa bootstrap confidence intervals, and two-tailed testing at the 0.05 significance level. The HTMT test results have been ascertained and the results also show that the confidence interval does not show a value of 1 on any of the constructs and indicating that all HTMT values are significantly different from 1 (Henseler, Ringle and Sarstedt, 2014) and this is also confirmed discriminant validity. Based on the results of Fornell and Larcker Criterion test and HTMT, all the results fulfill the requirement, indicating adequate and good discriminant validity.

Table 4: HTMT

\begin{tabular}{lccccccc}
\hline & AT & PI & PPS & PR & PQ & SI & SL \\
\hline \multirow{2}{*}{ AT } & & & & & & \\
& & & & & & \\
PI & 0.72 & & & & & \\
& $(0.604$, & & & & & \\
& $0.81)$ & & & & & \\
PPS & 0.353 & 0.336 & & & & \\
& $(0.223$, & $(0.228$, & & & & \\
& $0.482)$ & $0.463)$ & & & & \\
PR & 0.541 & 0.459 & 0.303 & & & \\
& $(0.441$, & $(0.330$, & $(0.181$, & & & \\
& $0.639)$ & $0.555)$ & $0.408)$ & & & \\
PQ & 0.202 & 0.15 & 0.147 & 0.152 & & \\
& $(0.107$, & $(0.074$, & $(0.090$, & $(0.077$, & & \\
& $0.314)$ & $0.234)$ & $0.210)$ & $0.198)$ & & \\
SI & 0.378 & 0.254 & 0.233 & 0.252 & 0.184 & \\
& $(0.245$, & $(0.151$, & $(0.142$, & $(0.147$, & $(0.098$, & \\
& $0.484)$ & $0.358)$ & $0.300)$ & $0.352)$ & $0.278)$ & \\
SL & 0.325 & 0.364 & 0.163 & 0.146 & 0.109 & 0.412 & \\
& $(0.207$, & $(0.217$, & $(0.077$, & $(0.069$, & $(0.045$, & $(0.296$, & \\
& $0.464)$ & $0.490)$ & $0.244)$ & $0.287)$ & $0.136)$ & $0.531)$ \\
\hline
\end{tabular}

Note: The values in the brackets represent the lower and upper bounds of the $95 \%$ confidence interval 


\section{Analysis of Structural Model and Hypothesis Testing}

It is very important to ensure that there is no lateral collinearity issue in the structural model. All the Inner VIF values for the independent variables (perceived quality, perceived product similarity, perceived risk, store loyalty, and store image) are less than 5 and 3.3, hence, collinearity is not a concern (Hair et al., 2016). The model's predictive accuracy is examined via a coefficient of determination scores (R2). The R2 values of the dependent variables (purchase intention) and the mediating variables (attitude towards using PLBs) are 0.388 and 0.337 respectively. This shows that R2 values are above the threshold of 0.33 (Chin, 2010) and indicate a moderate model. Path coefficient was assessed to determine the significance of hypotheses using the bootstrap resampling technique (5000 re-sample). In this light, the value of the path coefficient must be greater than 0.1 and significant at the level of 0.01 (Hair et al., 2010). Based on Table 5 and Figure 2, the t-values after the bootstrapping procedure show that all hypotheses are supported; the first five hypotheses (H1 until H5) are supported, with Perceived quality $(\beta=0.343, t=5.686, p<0.01)$, perceived product similarity $(\beta=0.188$, $\mathrm{t}=3.461, \mathrm{p}<0.01)$, perceived risk $(\beta=-0.135, \mathrm{t}=2.259, \mathrm{p}<0.01)$, store loyalty $(\beta=0.174$, $\mathrm{t}=2.976, \mathrm{p}<0.01)$ and store image $(\beta=0.145, \mathrm{t}=2.224, \mathrm{p}<0.01)$ found to have positive relationships with attitude towards using PLBs. H6 is also supported, indicating that attitude towards using PLBs positively influences purchase intention $(\beta=0.623$, $\mathrm{t}=11.543, \mathrm{p}<0.01)$.

According to Cohen (1988), f2 of 0.02 is considered as small, 0.15 is medium and 0.35 is large. Not surprisingly, the highest $\mathrm{f} 2$ was found in the relationship between attitude toward using PLBs and purchase intention which is 0.634 . Perceived quality has the highest $\mathrm{f} 2$ on attitudes among the five factors with 0.161 . This shows that perceived quality is the most important factor in influencing attitude toward using PLBs, with a medium effect size. Meanwhile, perceived risk and store image (both $\mathrm{f} 2=0.026$ respectively), perceived product similarity ( $\mathrm{f} 2=0.048$ ) and store loyalty (f $2=0.04$ ) indicates have the lowest effect sizes on attitude. The predictive relevance of the model was examined using the blindfolding procedure. It states that if the Q2 value is larger than 0 , the model has a predictive relevance for certain endogenous constructs (Chin et al., 2020; Hair et al., 2016). The two Q2 values for attitudes $(\mathrm{Q} 2=0.237)$ and intention $(\mathrm{Q} 2=0.253)$ are more than 0 indicating that the model has a sufficient predictive relevance. The result shows small q2 effect sizes for perceived quality $(0.10)$, perceived product similarity (0.03), perceived risk (0.02), and store loyalty (0.02), and store image (0.02) on attitude. The effect of attitude on intention (0.237) indicates a medium q2 effect size.

Table 5: Results of Hypothesis Testing

\begin{tabular}{lcccccccccc}
\hline \multicolumn{2}{c}{ Hypotheses } & $\begin{array}{c}\text { Std } \\
\text { Beta }\end{array}$ & $\begin{array}{c}\text { Std } \\
\text { Error }\end{array}$ & $\begin{array}{c}\text { T- } \\
\text { value }\end{array}$ & $\begin{array}{c}\mathbf{P}- \\
\text { value }\end{array}$ & $\mathbf{R}^{\mathbf{2}}$ & $\mathbf{f}^{2}$ & $\mathbf{Q}^{2}$ & $\mathbf{q}^{2}$ & Decision \\
\hline $\mathrm{H} 1$ & $\mathrm{PQ} \rightarrow \mathrm{AT}$ & 0.343 & 0.34 & 5.686 & 0.00 & 0.161 & & 0.10 & Supported \\
$\mathrm{H} 2$ & $\mathrm{PPS} \rightarrow$ AT & 0.188 & 0.198 & 3.461 & 0.00 & 0.048 & & 0.03 & Supported \\
$\mathrm{H} 3$ & $\mathrm{PR} \rightarrow \mathrm{AT}$ & -0.135 & -0.142 & 2.529 & 0.01 & & 0.026 & 0.02 & Supported \\
$\mathrm{H} 4$ & $\mathrm{SL} \rightarrow \mathrm{AT}$ & 0.174 & 0.173 & 2.976 & 0.00 & & 0.04 & & 0.02 & Supported \\
$\mathrm{H} 5$ & $\mathrm{SI} \rightarrow$ AT & 0.145 & 0.142 & 2.224 & 0.01 & 0.388 & 0.026 & 0.253 & 0.02 & Supported \\
$\mathrm{H} 6$ & $\mathrm{AT} \rightarrow$ PI & 0.623 & 0.625 & 11.543 & 0.00 & 0.337 & 0.634 & 0.237 & 0.237 & Supported \\
\hline
\end{tabular}

Note: $\mathrm{AT}=$ Attitude towards using PLB, PI = Purchase Intention, PPS = Perceived Product Similarity, $\mathrm{PQ}=$ Perceived Quality, SL = Store Loyalty, SI = Store Image. 


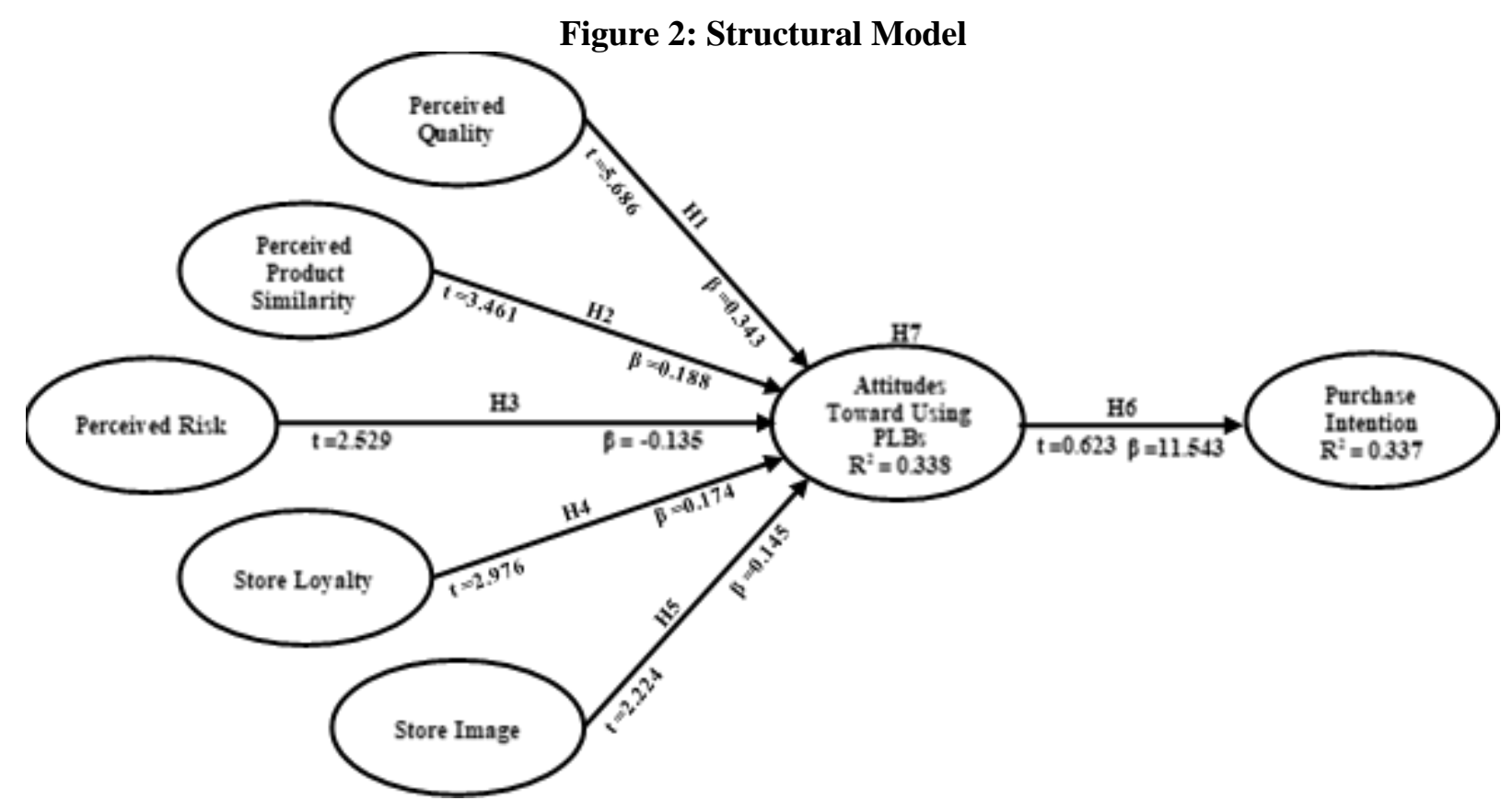

\section{Mediation Analysis}

Table 6 shows the results of mediation analysis. Bootstrapping procedures were also applied to examine the mediation effect (Preacher \& Hayes, 2004). It has shown that all five indirect effects are supported, $\mathrm{H} 7 \mathrm{a}(\beta=0.214, \mathrm{t}=4.97, \mathrm{CI}=0.137,0.305), \mathrm{H} 7 \mathrm{~b}$ $(\beta=0.117, \mathrm{t}=3.458, \mathrm{CI}=0.05,0.18), \mathrm{H} 7 \mathrm{c}(\beta=-0.084 ; \mathrm{t}=2.473, \mathrm{CI}=-0.144,-0.009), \mathrm{H} 7 \mathrm{~d}$ $(\beta=0.108, \mathrm{t}=2.599, \mathrm{CI}=0.022,0.183)$ and $\mathrm{H} 7 \mathrm{e}(\beta=0.09, \mathrm{t}=2.148, \mathrm{CI}=0.009,0.182)$. The indirect effect $95 \%$ Boot confidence interval Bias Corrected do not straddle a 0 in between indicating there is a mediation (Preacher \& Hayes, 2004).

Table 6: Results of Mediation Analysis

\begin{tabular}{|c|c|c|c|c|c|c|c|}
\hline & Hypotheses & Std. & Std & Confide & Interval & T-value & Decision \\
\hline & & & & $\begin{array}{c}\text { Lower } \\
\text { Limit }\end{array}$ & $\begin{array}{l}\text { Upper } \\
\text { Limit }\end{array}$ & & \\
\hline $\mathrm{H} 7 \mathrm{a}$ & $\mathrm{PQ} \rightarrow \mathrm{AT} \rightarrow \mathrm{PI}$ & 0.214 & 0.214 & 0.137 & 0.305 & 4.97 & Supported \\
\hline $\mathrm{H} 7 \mathrm{~b}$ & $\mathrm{PPS} \rightarrow \mathrm{AT} \rightarrow \mathrm{PI}$ & 0.117 & 0.122 & 0.05 & 0.18 & 3.458 & Supported \\
\hline $\mathrm{H} 7 \mathrm{c}$ & $\mathrm{PR} \rightarrow \mathrm{AT} \rightarrow \mathrm{PI}$ & -0.084 & -0.089 & -0.144 & -0.009 & 2.473 & Supported \\
\hline $\mathrm{H} 7 \mathrm{~d}$ & $\mathrm{SL} \rightarrow \mathrm{AT} \rightarrow \mathrm{PI}$ & 0.108 & 0.115 & 0.022 & 0.183 & 2.599 & Supported \\
\hline $\mathrm{H} 7 \mathrm{e}$ & $\mathrm{SI} \rightarrow \mathrm{AT} \rightarrow \mathrm{PI}$ & 0.09 & 0.089 & 0.009 & 0.182 & 2.148 & Supported \\
\hline
\end{tabular}

\section{Moderation Analysis}

Table 7 shows the results of moderating effect for product category and retail format. It was found that product category (Grocery $\mathrm{v}$ Non-grocery) and retail format (Supermarket v Drugstore) significantly moderate the effect of attitude and purchase intention. Therefore, hypotheses H8a and b are supported. 
Table 7: Results of Moderation Analysis

\begin{tabular}{|ccccc|cc}
\hline & Relationship & $\begin{array}{c}\text { Std. } \\
\text { Beta }\end{array}$ & $\begin{array}{c}\text { Std. } \\
\text { Error }\end{array}$ & $\begin{array}{c}\text { T- } \\
\text { value }\end{array}$ & $\begin{array}{c}\text { P- } \\
\text { value }\end{array}$ & Decision \\
\hline H8a & $\begin{array}{c}\text { Attitude*Product Category } \\
\rightarrow \text { Purchase Intention }\end{array}$ & 0.179 & 0.077 & 2.325 & 0.01 & Supported \\
H8b & $\begin{array}{c}\text { Attitude*Retail Format } \\
\rightarrow \text { Purchase Intention }\end{array}$ & 0.209 & 0.086 & 2.419 & 0.01 & Supported \\
\hline
\end{tabular}

Figure 3: Grocery v Non-grocery

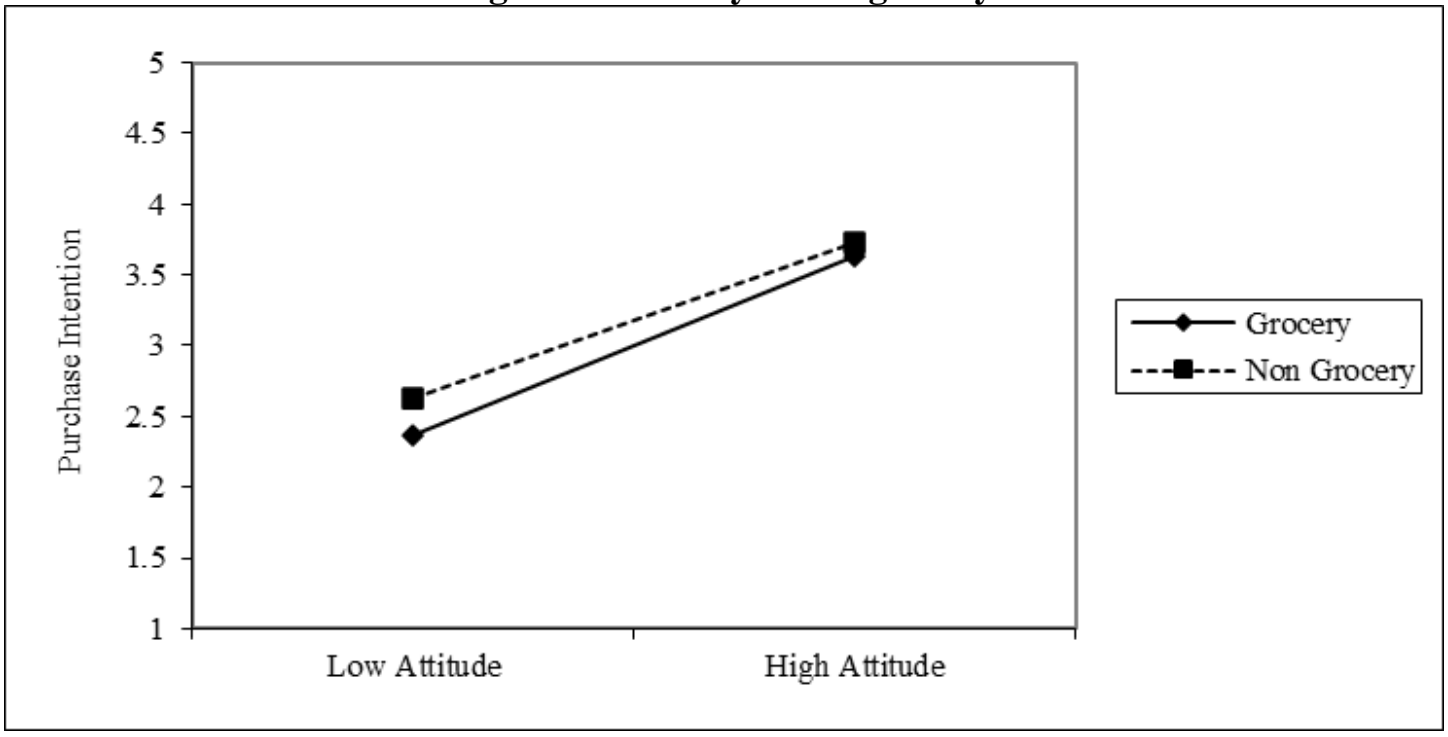

Figure 4: Supermarket v Drugstore

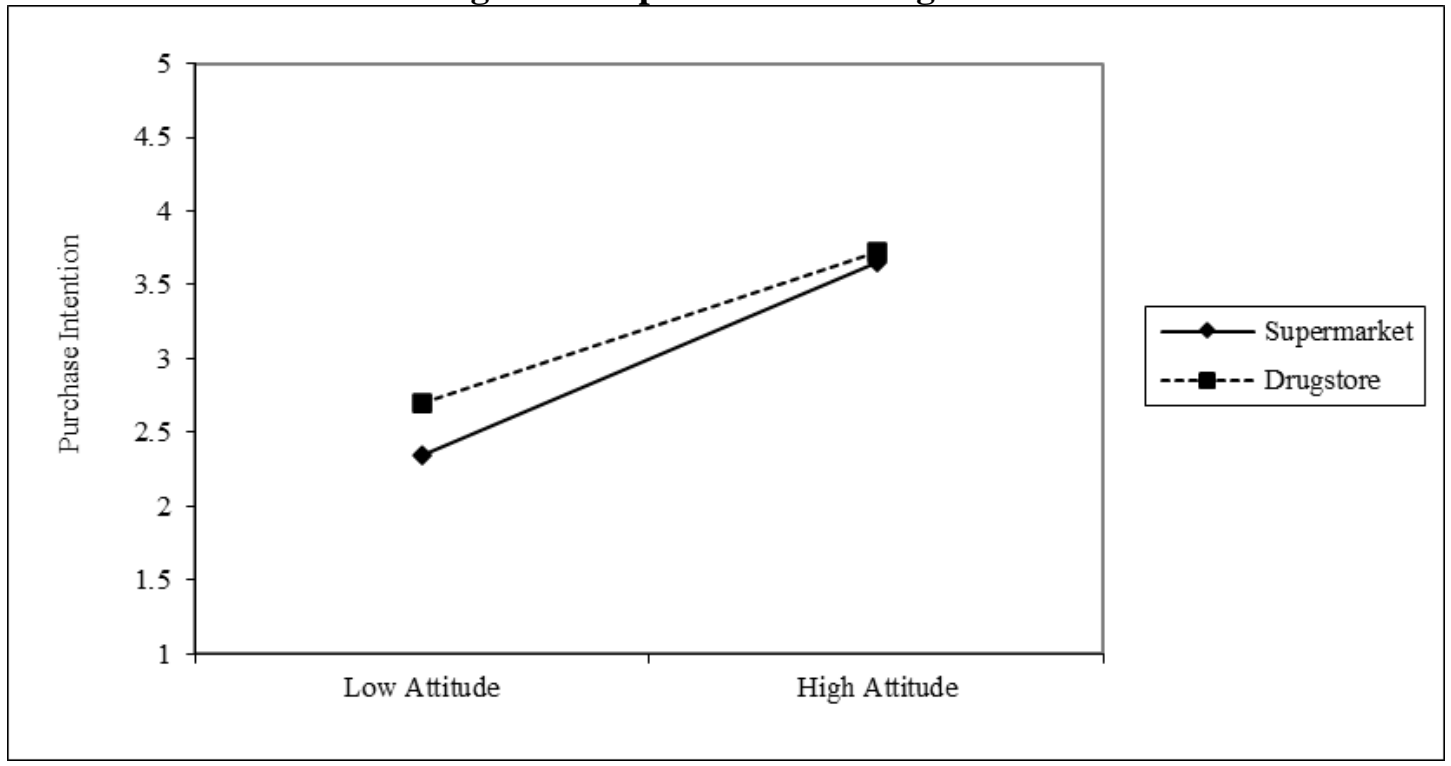




\section{Discussion}

PLBs is an interesting field in retail particularly in Malaysia where the development of PLBs is still in its infancy. This study examined Gen Y customers' attitude and behavioural intention toward PLBs. Gen Y customers who are also known as echo boomers and the millennium generation are born between 1980 and 1996 (Schiffman \& Wisenblit, 2015). Representing the largest market segment in Malaysia, their attitude and intention to buy PLBs could determine the success of PLBs. Five store-related factors (exogenous variables) were identified and examined namely perceived quality, perceived product similarity, perceived risk, store loyalty, and store image for their impacts on attitude (mediator) and purchase intention (endogenous variable). Two moderating variables were also included in the framework (product category and retail format).

The findings of this study show that PLBs marketers need to improve quality to exceed customers' expectations in order to attract them (Souki et al., 2019). This finding is consistent with the findings of Vo and Nguyen (2015) in which quality plays an important role in increasing customer purchase intention. In this light, a higher perception of quality in PLBs will lead to higher purchase behaviour (Mirabi, Akbariyeh and Tahmasebifard, 2015).

PLBs often imitate a new product launched by a national brand (Lamey, Deleersnyder, Steenkamp \& Dekimpe, 2018) to reduce development cost and reduce the risk of product failure (Ter Braak, Geyskens \& Dekimpe, 2014). In this study, the more Gen Y customers are not able to differentiate between the PLBs and national brands, the more positive their attitude towards using PLBs will be. With a lower price but similar product attributes, a PLB becomes an attractive option to customers. It is hence very important for marketers to create a PLB that is not too much different from the other national brands in creating a point of competitive advantage between retailers when the customers make purchases. This indicates that retailers should continue to gain knowledge from competitors to improve their PLBs (Gómez-Suárez \& Abril, 2016).

Perceived risk causes customers to feel uncertain and dissatisfied with the product or services (Aldousari et al., 2017). This is especially true in the case of highly unfamiliar products or new products (McClure \& Seock, 2020) such as PLB. Therefore, it is critical for marketers to reduce perceived risk on PLBs to avoid uncertainties among Gen Y customers that PLBs are an unwise decision and not a good buying that could not meet their expectations.

The significant relationship between store loyalty and attitude confirmed the important role PLBs in building store loyalty as PLBs are exclusively available at specific retailers while national brand products are usually available at many different retailers (Coelho do Vale, Matos \& Caiado, 2016). Loyalty programs such as membership cards could be effective in retaining customers and help retailers segment customers according to their preferences. At the same time, a good quality product is important for customer consideration to stay loyal to a store (Calvo-Porral \& Lévy-Mangin, 2017).

Store image is found to significantly affecting customer attitudes toward buying PLBs. The finding corroborated Elseidi and Metawie (2017)'s study in which shoppers with positive store image perception tend to hold a more positive attitude toward PLBs. It is 
very important for retailers to improve their store image to present an attractive image to ensure that each store has an interesting or unique appeal, for instance, the store layout should make it easier for customers to find the products. The employees also need to be knowledgeable and courteous, and lastly, the store needs to have a clear return policy and convenient operating hours.

This study also found that customers' attitude plays a significant role in forming a PLB related buying intention. Attitude towards PLBs is a predisposition of customers' favourable or unfavourable attitude to a PLB and their purchase behaviour or selfevaluation (Elseidi \& Metawie, 2017). As customer's attitude towards PLBs is changing, retailers need to modify and improve their products by providing higher quality products and adding value into their products.

Attitude towards using PLBs was proven to be a significant mediator in the relationships between the stores' related factors and purchase intention. Customers who perceived the quality as good, with higher perceived product similarity, store loyalty, and store image as well as lower perceived risk would form a more favourable attitude toward using PLB, and further form a higher purchase intention.

The findings show that intention to buy PLB increases whenever attitudes become more favourable in both retail format and product category context. However, more favourable attitudes are needed to form the intention to buy grocery PLB than nongrocery PLBs. This could be due to the nature of the non-grocery PLBs which are generally exclusive and unavailable in other non-grocery stores. Meanwhile, for grocery stores which sell more food and staple products, despite the different brand names, these products are rather similar across different retailers. Consequently, customers would require more favourable attitudes towards grocery PLBs to form the intention to buy compared to the non-grocery PLBs. A similar explanation could be extended to the retail format context. Customers who shop PLBs in supermarkets require more favourable attitudes toward PLBs compared to PLBs in drugstores to form buying intention. Many well-known drugstore chains are selling their own exclusive PLBs. Customers would have to patronage a particular drugstore to acquire the PLBs. Meanwhile, supermarkets are generally selling staple and food products which a similar product is available in other supermarkets, making more favourable attitudes needed to form purchase intention.

\section{Theoretical and Managerial Implications}

Numerous studies on Gen Y customers focus on their online purchases (Muda, Mohd \& Hassan, 2016), brand loyalty (Ordun, 2015) as well as technology use (Kothandaram, 2015). However, studies of Gen Y customers in term of their attitudes and behavioural intention towards PLBs particularly in Malaysia is lacking. This study contributes toward PLBs literature. Among the five store-related factors, perceived quality is found to be the strongest predictor of attitude toward PLBs, followed by perceived product similarity between PLBs and national brands. The findings also indicate that attitude toward using PLBs has a strong impact on purchase intention. Retail format and product category moderated the relationship between attitude and purchase intention. 
Besides, the study extends the study by Thanasuta (2015) by examining the storerelated variables. This finding of this study contributes to a better understanding of customer purchase intention, particularly among the Gen Y customers. Customers form attitudes based on their experience, feeling, and belief (Lin, Gao \& Safar, 2018) towards a particular product. It was also found that other elements, such as perceived quality, perceived product similarity, perceived risk, store loyalty, and store image also contribute significantly to attitudes and buying intention of PLBs.

This study is among a handful of studies examining PLBs in Malaysia. There are several managerial implications that need to be considered. First, the study demonstrates that the perceived quality of PLBs affects purchase intention. Gen Y believes that their consumption choices mirror who they are (Smilansky, 2016). The perception that the PLBs are having equally good quality as the national brands will help form a positive attitude and purchase intention. Therefore, retailers should focus on improving the quality of the PLBs.

Second, the packaging and attributes of the product play an important role to capture customers' intentions. Most of the time, customers are less concerned with products' attributes when choosing between national or PLBs. It is important for retailers to be innovative and creative in product packaging. The findings of this study indicate that high similarity between PLBs and national brands would lead to favourable attitude. In other words, Gen Y customers do not differentiate or discriminate the products in retail stores and this provides an advantage for 'me too' or copycat PLBs product. PLBs marketers could enhance on the similarity between their brands and the national brands in terms of product features and packaging to build interest and awareness. Nevertheless, they also need to consider ethical and legal issues while adopting these strategies.

It is a known fact that uncertainty and risks could deter customers from choosing PLBs despite the spectacular promotion activities. This is especially true among Gen $\mathrm{Y}$ customers who are known to ensure that they make the best choice prior to purchasing a product (not only price and quality). They have to be convinced that it is a good investment for the future. As they often place high confidence and trust in the brand of their choice (Ordun, 2015), retailers must consider reducing the quality gap between PLBs and national brands. Offering penetration pricing strategy could also be effective because high prices discourage customer to try PLBs, hence, products trial is an important strategy to promote PLBs (Aldousari et al., 2017). As Gen Y is cautious in spending, retailers should also consider pricing as an important factor. Hence, future studies could be extended to examine the price value effect.

Fourth, loyal customers to a retail store are found to patronage the same store repeatedly, spread positive words of mouth about the store, and engage in lesser brand switching (Savila, Wathoni \& Santoso, 2019). The finding supports the notion that store loyalty leads to a positive attitude and further causes higher buying intention of PLBs. It is hence very important for retailers to link PLBs to store loyalty and store image. Membership card programs are an attractive strategy as it offers special promotion or benefit for customers who are loyal towards PLBs. Such a strategy will help to increase awareness, create interest, and subsequently, the form of positive attitude and buying intention. This is particularly significant in this case as Gen Y customers are characterised as more prompt for brand switching. However, once they are comfortable 
with something, they could be very loyal users (Smilansky, 2016). It is important to make sure the store is working on offering a loyalty program which is convenient and relevant to them.

Fifth, retailers must consistently convey a good image of their store and link it to PLBs. In customers' minds, store image is the total sum of appearance the store portrays to the customers. Retailers must improve their images through relationships with clients and customers that can accentuate their esteem. This will create goodwill between the customers and the store which will be beneficial to both. Customers will have less resistance to try PLBs marketed by retailers with a preferable image.

This study confirms that attitude mediated the relationships between the store-related factors and purchase intention. It is therefore important for retailers to consider all storerelated factors such as quality, similarity, risk, store loyalty, and store image to form a positive attitude and later the intention to buy PLBs. Retailers also need to consider customers' tendency towards the product category and retail format in order to attract customer intention to buy PLBs product. Grocery retailer such as supermarkets should create exclusive PLBs which are unavailable in other stores, not only differentiated by names but also product quality designs, features, and benefits.

\section{Further Research Directions and Conclusions}

There are a few limitations in this study. First of all, the data were collected around the Greater Kota Kinabalu area which limits the generalisability of data. Future researchers could extend the research to other cities or areas in Sabah. Second, this study only involved two retail formats whereas in the future more retail formats could be investigated to include different sectors and more variables. Third, this study focused on the PLBs and store-related characteristics. In the future, researchers could further examine variables such as demographics (income and gender) and behavioural patterns (user status and buying pattern). The inclusion of these variables will provide valuable insights to retailers and academicians. This study aims to investigate and understand the attitude of Gen Y customers in Malaysia and could help predict future purchase intention towards PLBs. In order to build favourable customer attitudes and eventually, purchase intention, this study suggests factors such as perceived quality, perceived product similarity, perceived risk, store loyalty, and store image must be given extra attention. PLBs could bring value to both retailers and customers. It is also important to note that the more favourable attitude towards PLBs will bring higher purchase intention.

\section{Practical Implications for Asian Business}

This research investigates the attitudes and intention to buy PLBs among Gen Y customers who are also known as echo boomers and millennium generation, the largest customer segment in Malaysia. In Asian context especially in Malaysia, PLBs still lacks acceptance compared to Europe or Western country. The market requires closer examination where the demand is still discouraging. This finding will help retailers to reach out to the right customers. Gen Y customers have a big potential to focus them on marketing activities. Their spending habit is different which in future develop and 
change the landscape in retailing in term of buying decision when it compared to baby boomers. They also like to try something new and retailers need to promote PLBs more often to attract their attention and exceed their expectations and thus lead to increase purchase intention and sales.

Customers always make a comparison between PLBs and national brands. But for a certain condition, the most important thing is that the same attributes can fulfill customers' needs and wants. Increased on the cost of living and reduced income are becoming some of the challenges faced by the customers. Therefore, due to unfavourable economic conditions, customers tend to be sensitive especially for lower and middle households. PLBs can be one of the solutions to adapt to the situation which offers minimum quality with the affordable price range. Purchase intention can be arisen when the customers have the ability to pay for products. PLBs also can act as a substitute for national brands.

During the pandemic of COVID-19, its consequences have led to changes in consumer behaviour. Customers tend to try a different brand, even though there are no large indications on shifts in preferred brands, health consciousness, and qualitative demands on brands due to the pandemic. This shows the potential of PLBs in times of crisis because most people are affected by the situation. Price, quality, risk, and loyalty play important roles in the pandemic in the context of the health aspect of the COVID-19 virus.

Asian people's lack of trust and tend to avoid risks and always want to make a good investment. Therefore, loyalty programs of membership cards could be effective in retaining customers and helps retailers to segment customers according to their preferences because Asian people willing to stay loyal to something that benefits them. Customers who are normally loyal to a certain product or brand could find it difficult to switch to another brand and product and they are less likely to find a substitution. Competition between PLBs and NBs will boost the retail industry in Asia, thus customers will have more choices to shop with. PLBs are not only differentiated by names, but by quality, design, features, and benefits. Knowledge of predictors about PLBs purchase intention may help in the development of appropriate marketing strategies to address customer's attitudes that can increase purchase intention. Therefore, retailers need to understand and learn to use modern marketing and strategies techniques such as social media which is the current interaction platform for Gen Y.

This study will help the retailers to look at the area that will become a focus point for customers when making a purchase decision. Quality act as a key indicator to attract customers' intention and customers' expectation on the product's excellent and superiority attributes. Retailers should stress on the packaging and features of the PLBs to enhance their similarity with the NBs. Gen Y will make sure that they make the best choice in order to avoid negative comment from their social groups or family and will spread positive word-of-mouth, therefore, risk need to be handling with care to avoid negative perception about PLBs. 


\section{References}

Al-Debei, M. M., Akroush, M. N., \& Ashouri, M. I., (2015), "Consumer attitudes towards online shopping: The effects of trust, perceived benefits, and perceived web quality", Internet Research, vol. 25, no. 5, pp. 707-733.

Aldousari, A. A., Yasmin, F., Ab Yajid, M. S., \& Ahmed, Z. U., (2017), "Consumer evaluations of store brands: Effects of product-perceived risks", Journal of Transnational Management, vol. 22, no. 2, pp. 71-90.

Beneke, J., \& Zimmerman, N., (2014), "Beyond private label panache: The effect of store image and perceived price on brand prestige", Journal of Consumer Marketing, vol. 31, no. 4, pp. 301-311.

Boyle, P. J., \& Lathrop, E. S., (2013), "The value of private label brands to U.S. consumers : An objective and subjective assessment", Journal of Retailing and Consumer Services, vol. 20, no. 1, pp. 80-86.

Brannick, M. T., Chan, D., Conway, J. M., Lance, C. E., \& Spector, P. E., (2010), "What is method variance and how can we cope with it? A panel discussion', Organizational Research Methods", vol. 13, no. 3, pp. 407-420.

Calvo-Porral, C., \& Lévy-Mangin, J. P., (2017), "Store brands' purchase intention: Examining the role of perceived quality", European Research on Management and Business Economics, vol. 23, no. 2, pp. 90-95.

Cheah, I., Phau, I., \& Liang, J., (2015), “Factors influencing consumers' attitudes and purchase intentions of e-deals", Marketing Intelligence and Planning, vol. 33, no. 5, pp. 763783.

Chin, W. W., (2010), How to Write Up and Report PLS Analyses. Handbook of Partial Least Squares. Springer Handbooks of Computational Statistics: Springer, Berlin, Heidelerg, pp.655-690.

Chin, W., Cheah, J. H., Liu, Y., Ting, H., Lim, X. J., \& Cham, T. H., (2020), "Demystifying the role of causal-predictive modeling using partial least squares structural equation modeling in information systems research", Industrial Management \& Data Systems.

Coelho do Vale, R., Matos, P. V., \& Caiado, J., (2016), "The impact of private labels on consumer store loyalty: An integrative perspective", Journal of Retailing and Consumer Services, vol. 28, pp. 179-188.

Cohen, J., (1988), Statistical power for the social sciences. Hillsdale, NJ: Laurence Erlbaum and Associates.

Demirgüneş, B. K., (2014), "The antecedents of store image and customer satisfaction", International Journal of Research in Business and Social Science, Vol. 3, no. 3, pp. 4862.

Department of statistics Malaysia, (2020), "Population clock", retrieved from: http://www.dosm.gov.my/v1/index.php? (Accessed: 20 May 2020)

Diallo, M. F., Burt, S., \& Leigh, S., (2015), "The influence of image and consumer factors on store brand choice in the Brazilian market: Evidence from two retail chains", European Business Review, vol. 27, no. 5, pp. 495-512.

Diallo, M. F., \& Siqueira, J. R., (2017), "How previous positive experiences with store brands affect purchase intention in emerging countries: A comparison between Brazil and Colombia”, International Marketing Review, vol. 34, no. 4, pp. 536-558.

Douglas, S. P., \& Samuel Craig, C. S., (2007), "Collaborative and Iterative Translation: An Alternative Approach to Back Translation", Journal of International Marketing, vol. 15 , no. 1, pp. 30-43.

Elseidi, R. I., \& Metawie, M., (2017), "Antecedents and Consequences of Private label brand attitude in the Egyptian Retailers", Scientific Journal for Economic and Commerce, vol. 47, no. 1, pp. 997-1034. 
Erdil, T. S., (2015), "Effects of Customer Brand Perceptions on Store Image and Purchase Intention :an Application in Apparel Clothing", Procedia - Social and Behavioral Sciences, vol. 207, pp. 196-205.

Euromonitor International, (2013), "The new face of private label: Global market trends to 2018", Retrieved from: https://go.euromonitor.com/new-face-of-private-label-globalmarket-trends-2018-strategy-briefing.html (Accessed: 20 January 2018)

Fong, S. W. L., Kian, T. P., Fern, Y. S., \& Vincent, W., (2015), "Monetary and image influences on the purchase decision of private label products in Malaysia", Journal of Advanced Management Science, vol.3, no. 4, pp. 312-318.

Fornell, C., \& Larcker, D. F. (1981), "Evaluating Structural Equation Models with Unobservable Variables and Measurement Error", Journal of Marketing Research, vol. 18 , no. 1 , pp. $39-80$.

Gangwani, S., Mathur, M., \& Shahab, S., (2020), "Influence of consumer perceptions of private label brands on store loyalty - evidence from Indian retailing", Cogent Business \& Management, vol. 7, no.1, pp.1-19.

Gázquez-Abad, J. C., Martínez-López, F. J., Mondéjar-Jiménez, J. A., \& Esteban-Millat, I., (2015), "Mixed assortments vs. store brand-only assortments: The impact of assortment composition and consumer characteristics on store loyalty", Revista Española de Investigación de Marketing ESIC, vol. 19, no. 1, pp. 24-45.

Gold, A. H., Malhotra, A., \& Segars, A. H., (2001), "Knowledge Management: an Organizational Capabilities Perspective", Journal of Management, vol. 18, no. 1, pp. $185-214$.

Gómez-Suárez, M., \& Abril, C., (2016), Choice of national brand vs. private label "me-too" new products in a multicultural context: understanding consumer innovativeness, In Handbook of Research on Strategic Retailing of Private Label Products in a Recovering Economy.

Gómez-Suárez, M., Paiva, G., \& Schnettler, B., (2016), Private labels in Chile: Influential factors in the purchase intention, In Handbook of Research on Strategic Retailing of Private Label Products in a Recovering Economy.

Hair, J. F., Black, W. C., Babin, B. J., \& Anderson, R. E., (2010), Multivariate Data Analysis: A Global Perspective, In Multivariate Data Analysis: A Global Perspective.

Hair, J. F., Hult, G. T. M., Ringle, C., \& Sarstedt, M., (2016), A Primer on Partial Least Squares Structural Equation Modeling (PLS-SEM): Sage Publications.

Henseler, J., Ringle, C. M., \& Sarstedt, M., (2014), "A new criterion for assessing discriminant validity in variance-based structural equation modeling", Journal of the Academy of Marketing Science, vol. 43, pp. 115-135.

Hwang, C., Chung, T. L., \& Sanders, E. A., (2016), "Attitudes and Purchase Intentions for Smart Clothing", Clothing and Textiles Research Journal, vol. 34, no. 3, pp. 207-222.

Ing, P., Ivan, L. R. V., \& Osman, Z., (2019), "The Relationship Between Malaysian Supermarket In-Store Shopping Experiences and Positive Word-of-Mouth", International Journal of Marketing Studies, vol. 11, no. 2, pp. 115-130.

Johansson, T., \& Kask, J., (2017), "Configurations of business strategy and marketing channels for e-commerce and traditional retail formats: a qualitative comparison analysis (QCA) in sporting goods retailing", .Journal of Retailing and Consumer Services, vol. 34, pp. 326-333.

Kline, R.B., (2015), Principles and practise of structural equation modeling, Guilford Publications.

Komissarova, I. P., Mayorova, E. A., Nikishin, A. F., Rozhnova, O. V., \& Mayorova, A. N., (2017), "Private labels and product categories", Revista ESPACIOS, vol. 38, no. 62.

Kothandaram, A., (2015), "Gen-Y Attitude: E-Shopping in the Digital Age", International Journal of Science Technology and Management, vol. 4, no. 1, pp. 305-314.

Kotler, P., \& Armstrong, G., (2016), Principles of marketing, Pearson.

Kuswoyo., Suliyanto., \& Setyan, R. P., (2019), "The effect of perceived product-similarity towards decision making difficulty with consumer involvement as moderation: A study towards coffee consumers in Banjarnegara", International Conference on Rural 
Development and Enterpreneurship 2019 : Enhancing Small Business and Rural Development Toward Industrial Revolution 4.0, vol. 5, no.1, pp. 899-905.

Lamey, L., Deleersnyder, B., Steenkamp, J. B .E. M., \& Dekimpe, M. G. (2018), "New product success in the consumer packaged goods industry: a shopper marketing approach", International Journal of Research in Marketing, vol. 35, no. 3, pp. 432-452.

Lin, Y., Gao, Y., \& Safar, H., (2018), "Factors Influencing Purchase Intention of PLB's in Food Products from Azerbaijan Retailing Industry", European Journal of Business and Management, vol. 10, no. 21, pp. 107-120.

Manikandan, M. K. M., (2020), "Store brand and perceived risk on private label brand attitude", Journal of Indian Business Research, vol. 12, no. 1, pp. 133-150.

Mathur, M., \& Gangwani, S., (2016), "The Effect of Retail Store Image Dimensions on Consumer's Purchase Intention of Private Label Brands", International Journal of Research in Finance and Marketing (IJRFM), vol. 6, no. 11, pp. 89-102.

McCaskill, A., (2014), "Global Perceptions About Store Brands Improve, But Share of Basket Varies by Country", Retrieved from: https://www.nielsen.com/us/en/pressreleases/2014/global-perceptions-about store-brands-improve-but-share-of-basketvaries-by-country/(Accessed: 10 February 2019)

McClure, C., \& Seock, Y. K., (2020), "The role of involvement: Investigating the effect of brand's social media pages on consumer purchase intention", Journal of Retailing and Consumer Services, vol. 53.

Mirabi, V., Akbariyeh, H., \& Tahmasebifard, H., (2015), "A Study of Factors Affecting on Customers Purchase Intention Case Study: The agencies of Bono brand tile in Tehran", Journal of Multidisciplinary Engineering Science and Technology (JMEST), vol. 2, no. 1, pp. 267-273.

Mostafa, R. H. A., \& Elseidi, R. I., (2018), "Factors affecting consumers' willingness to buy private label brands (PLBs): Applied study on hypermarkets", Spanish Journal of Marketing - ESIC, vol. 22, no. 3, pp. 338-358.

Muda, M., Mohd, R., \& Hassan, S., (2016), "Online Purchase Behavior of Generation Y in Malaysia", Procedia Economics and Finance, vol. 37, pp. 292-298.

Norfarah, N., Koo, P. M., \& Siti-Nabiha, A. K., (2018), "Private label brand purchase intention: A Malaysian study", Global Business and Management Research: An International Journal, vol. 10, no. 1, pp. 197-215.

Nunnally, J., (1978), "Psychometric theory", Journal of Chemical Information and Modeling.

Ordun, G., (2015), "Millennial (Gen Y) Consumer Behavior Their Shopping Preferences and Perceptual Maps Associated With Brand Loyalty", Canadian Social Science, vol. 1, no. 4, pp. 40-45.

Podsakoff, P. M., MacKenzie, S. B., Lee, J. Y., \& Podsakoff, N. P., (2003), "Common Method Biases in Behavioral Research: A critical review of the literature and recommended remedies", Journal of Applied Psychology, vol. 88, no. 5, pp.879-905.

Preacher, K. J., \& Hayes, A. F. (2004), "SPSS and SAS procedures for estimating indirect effect in simple mediation models", Behaviour Research Methods, Instruments and Computer, vol. 36, pp. 717-731.

Savila, I. D., Wathoni, R. N., \& Santoso, A. S., (2019), "The role of multichannel integration, trust and offline-to-online customer loyalty towards repurchase intention: An empirical study in online-to-offline (O2O) e-commerce", Procedia Computer Science, vol. 161, pp. 859-866.

Schiffman, L. G., \& Wisenblit, J., (2015), Consumer Behavior, Pearson Education, Harlow.

Seenivasan, S., Sudhir, K., \& Talukdar, D., (2016), "Do store brands aid store loyalty?", Management Science, vol. 62, no. 3, pp. 802-816.

Smilansky, O., (2016), "GENERATION Y: In Control, Content, and Community-Minded", CRM Magazine.

Souki, G. Q., Antonialli, L. M., Barbosa, Á. A. d. S., \& Oliveira, A. S., (2019), "Impacts of the perceived quality by consumers' of à la carte restaurants on their attitudes and behavioural intentions", Asia Pacific Journal of Marketing and Logistics, vol. 32, no. 2, pp. 301-321. 
Ter Braak, A., Geyskens, I., \& Dekimpe, M. G., (2014), “Taking private labels upmarket: Empirical generalizations on category drivers of premium private label introductions", Journal of Retailing, vol. 90, no. 2, pp. 125-140.

Thanasuta, K., (2015), "Thai consumers' purchase decisions and private label brands", International Journal of Emerging Markets, vol. 10, no. 1, pp. 102 - 121.

The Nielsen Company, (2014), "The state of private label around the world, where it's growing, where it's not, and what the future holds", retrieved from: https://www.nielsen.com/wp-content/uploads/sites/3/2019/04/state-of-private-labelaround-the-world-nov-2014.pdf (Accessed: 17 February 2019)

The Nielsen Company, (2018), "The rise and rise again of private label", retrieved from :https://www.nielsen.com/wp-content/uploads/sites/3/2019/04/global-private-labelreport.pdf (Accessed: 17 February 2019)

Tomasevic, I., Novakovic, S., Solowiej, B., Zdolec, N., Skunca, D., Krocko, M., Nedomova, S., Kolaj, R., Aleksiev, G., \& Djekic, I., (2018), "Consumers' perceptions, attitudes and perceived quality of game meat in ten European countries", Meat Science.

Valaskova, K., Kliestikova, J., \& Krizanova, A., (2018), "Consumer perception of private label products: An empirical research", Journal of Competitiveness, vol. 10, no. 3, pp. 149163.

Van de Vijver, F., \& Hambleton, R. K., (1996), “Translating tests: Some practical guidelines”, European Psychologist, vol. 1, no. 4, pp. 89-99.

Vo, T. T., \& Nguyen, C. T., (2015), "Factors influencing customer perceived quality and purchase intention toward private labels in the Vietnam market: The moderating effects of store image", International Journal of Marketing Studies, vol. 7, no. 4, pp. 51-63.

Wang, J., Tao, J., \& Chu, M., (2020), "Behind the label: Chinese consumers' trust in food certification and the effect of perceived quality on purchase intention", Food Control, vol. 108.

Wang, L., Jin, M., \& Yang, Z., (2020), "Regulatory focus and consumption of counterfeit luxury goods: Roles of functional theories of attitudes and perceived similarity", Journal of Business Research, vol. 107, pp. 50-61.

Zhang, B., \& Kim, J. H., (2013), "Luxury fashion consumption in China: Factors affecting attitude and purchase intent", Journal of Retailing and Consumer Services, vol. 20, no. 1, pp. 68-79. 